\author{
Anna Pawlikowska-Piechotka* \\ Anna Ostrowska-Tryzno** \\ Joseph Pilsudski AWF University Warsaw
}

\title{
INNOVATIVE LOCAL COMMUNITY PARTNERSHIP AND SUSTAINABLE URBAN TOURISM - THE OLD TOWN IN WARSAW
}

\begin{abstract}
It is a fact that in the past decades several of Polish towns and cities functioned as popular tourist destinations, but heritage tourism and especially one of its segments urban tourism - has grown significantly in recent years. As a result of socio-economic transformation, more income, higher levels of education, growing awareness of our country, globalization process (access to EU) and better tourist infrastructure (transport, accommodation) now we can experience bigger tourists interest in our historic cities. Today especially Cracow and Warsaw have been visited by millions of tourists per year. Needless to say that the main attraction for tourists there are the historic centres of these cities, the Old Town in Warsaw and the Old Town in Cracow.
\end{abstract}

Keywords: historic cities, sustainable tourism, innovate partnership, local community

\section{Research question and methods}

As tourism develops in the historic centres, it brings about recognisable ecological, cultural, social and economic transformations. Today the tension clearly exists between users of "shared space", between visitors and those who

* E-mail address: anna.piechotka@gmail.com.

** E-mail address: anna.tryzno@gmail.com. 
work and live in and around heritage sites. Different and sometimes competing requirements should be reconciled especially in the context of balancing the needs of visitors and residents of a site. Our research study (conducted by the author in the Joseph Pilsudski AWF University Warsaw, 2010-2014) concerns the phenomenon of heritage tourism and its impact on local community members of the Old Town in Warsaw. We are interested both in the negative and the positive consequences, in revealing the socio-cultural impacts that cultural tourism has on the historic district residents (host community). We intend to shape our research in the form enabling us to achieve applied results and hope to find a solution for the sustainable heritage tourism development. To measure these issues from the different perspectives we use the combination of methods as our aim has been to achieve a balance between quantitative and qualitative approaches: the academic studies of published resources and the spatial plans (quantitative secondary data analysis) as well as the case study - primary data in the form of observations, semi-structured and structured interviews, conducted between the local community and the local authority representatives.

\section{Results and Conclusions}

Our research demonstrates that the most important aspects of the physical damage at the historic site are wear and tear, litter, pollution, noise and vandalism. The throngs of people filling the narrow streets and anti social behaviour of some of the tourists are the major disruptions listed by the local community members of the Old Town in Warsaw. Some of the locals mentioned the lack of shops with food and very high prices at the few groceries which are today in the minority among the numerous restaurants, banks, fancy boutiques and souvenir shops - targeting with their offer rich tourists and much less interested in the residents group. Sadly, very active in the past, the Association of Old Town Residents (founded in 2000) today cannot contribute as effectively in shaping the spatial policy as potentially it could because most of its members have not legal rights to their apartments. Without the clear position, they are treated only as the tenants of communal properties and as a "weak" partner for the Warsaw City Council Office. in order to obtain an equilibrium between the potential tourism growth, conservatory needs and quality of the host community life, all stakeholders' interests and objectives regarding tourism development must 
be incorporated in the Local Planning process (conservatory, hosts and visitors taken into account). To answer these questions, a present planning process should be revised and a more integrated approach to local planning will be applicable as an attempt to solve spatial conflicts and to build higher tolerance between local community members and tourists when sharing the historic space. Our proposal of the integrated planning process for the Old Town in Warsaw is aimed at addressing the unique feature and specific nature of this site and to find a balance between the conservation needs, heritage tourism development and the local community expectations.

\section{Introduction}

It is a fact that in the past decades several of the Polish towns and cities have functioned as popular tourist destinations, but heritage tourism and especially one of its segments - urban tourism - has been growing significantly in the recent years. As a result of socio-economic transformations, growing income, higher levels of education, growing awareness of our country, globalisation process (access to EU) and better tourist infrastructure (transport, accommodation), we can now experience tourists' greater interest in our historic cities. Moreover, our cities, as tourist destinations, offer to Western European visitors some fascinating but relatively low-cost cultural experiences. Interestingly, although many Polish historic cities are currently attempting to diversify their tourism offer (as spa tourism) - cultural and heritage tourism has remained the most popular. Today especially Cracow and Warsaw are popular, visited by millions of tourists per year (in 2009: Warsaw by 8900000 and Cracow by 4100 000), by people coming from Poland (71\%) and abroad (29\%). The origin of oversees tourists is mainly Germany $(12.0 \%)$, Spain $(10.8 \%)$, UK $(9.9 \%)$, France $(9.8 \%)$ and US $(9.0 \%) .{ }^{1}$ The average stay amounts to about 6 days, but Warsaw and Cracow are also visited by millions of one-day excursionists, not staying overnight (Warsaw by 3200000 per year). ${ }^{2}$

Needless to say, the main attraction for tourists and for one-day excursionists are the historic centres: the Old Town in Warsaw and the Old Town

\footnotetext{
1 http://www.intu.gov.pl.

2 Ibidem.
} 
in Cracow - both sites having the prestigious UNESCO World Heritage Site status. As other UNESCO Heritage Sites, the Old Towns in Cracow and the Old Town in Warsaw are very popular, in some summer months even extremely overcrowded and they need to develop and apply a new approach to tourism development. This is not a new problem and a number of possible negative consequences of tourism in the historic sites has already been mentioned by scholars some years ago. ${ }^{3}$ For example, different local society groups or individuals may benefit or suffer disproportionately from the tourist development, what leads to unwelcomed tensions, and often opened conflict. However, today we have the knowledge and planning tools enabling to minimize negative effects on historic, natural and social environment. Still - it is not too late for the Old Town in Warsaw, and now there is an urgent need to shape a rational strategic planning to the site management in order to safeguard the outstanding values of heritage, protect local community wellbeing and achieve sustainable tourism and economic development of the region.

Today residents of the Old Town in Warsaw form a very special community group and living among historic monuments they have developed a strong sense of tradition and heritage on one hand, and, at the same time, a grudge towards tourism on the other. Most of the local community members have been living in the Warsaw Old Town since 1950, in what in the post-WWII reconstruction period has been known as the "communal apartment." Today it seems that they truly care for the historic fabric preservation, restoration and maintenance, being very proud of the tradition and symbolic meaning of the site. Yet, as tourism develops in this historic centre, it brings about recognisable ecological, cultural, social and economic changes, most of them very damaging from the local community point of view. For example, the re-introduction of the market economy in Poland has changed the landscape and, to meet tourist demands, many B\&B, hostels, restaurants, night clubs opened in the Old Town area replacing grocery shops, milk-bars and local bookshops. One can notice that the tension clearly

3 G.J. Ashworth, Heritage Planning: an approach to Managing Historic Cities, in: Managing Historic Cities, ICC Kraków 1997, pp. 27-49; G.J. Ashworth, Whose history, whose heritage? Management means choice, in: Managing Tourism in Historic Cities, ICC Kraków 1992, pp. 57-67; D. Goetz et al., Stakeholder involvement in sustainable tourism: balancing the voices, in: Global Tourism, ed. W.F. Theobald, Elsevier, Burlington 2005, pp. 230-248; M. Paszucha, Historic City Tourism and Polish Tourism Policy, in: Managing Tourism in Historic Cities, ICC, Kraków 1997, pp. 37-43; M. Selby, Understanding Urban Tourism: Image, Culture, Experience, I.B. Tauris, London 2004. 
exists between users of the "shared space:" visitors to the Old Town in Warsaw and those who work and live in and around heritage site.

On the other hand, the development of the tourist industry is more than a question of economic necessity; it is a chance to contribute to a better protection of historic monuments and, in the broader perspective, to urban regeneration. In consequence, this situation calls for new solutions in establishing the sustainable interrelationships between both the preservation of heritage potential of the Old Town and of the New Town in Warsaw, tourist development and satisfactory services there. At the same time, the local community must have strong rights to meet their expectations, needs and no changes in their everyday life routine guaranteed. Is it right to be interested in the Old Town community as one of the basic units of tourism development? Some scholars argue that from a postmodernist perspective and as a consequence of increasing mobility of society, global communication, there is no point in such a studies, while some insist on taking the opposite approach. ${ }^{4}$ However, the Old Town in Warsaw differs from those in London or New York in that most of its residents are long-term and the core is formed by place-based families permanently identified with the site (often the second or third generation).

\section{Research questions and methods}

Our research study (conducted by the authors in the Faculty of Tourism and Recreation Joseph Pilsudski AWF University Warsaw, 2010-2014) concerns the phenomenon of heritage tourism and its impact on the cultural values and the local community members inhabiting the Old Town in Warsaw. The assumption is to develop a fully integrated, interdisciplinary approach while addressing the complex issue of the Old Town characteristics and heritage tourist development implications. We are interested both in the negative and the positive

4 J.E. Innes et al., Reframing public participation: strategies for 21st century, "Planning Theory \& Practice" 2004, Vol. 5, No. 4, pp. 419-436; M.B. Lane, Public Participation in Planning: an intellectual history, “Australian Geographer” 2005, Vol. 36, No. 3, pp. 283-299; A. Panasiuk, Instrumenty polityki turystycznej na poziomie regionalnym i lokalnym, in: Nowe wyzwania gospodarki turystycznej na poziomie lokalnym, regionalnym i międzynarodowym, Białystok 2011, pp. 87-107; G. Richards et al., The community: a sustainable concept in tourism development?, in: Tourism and sustainable community development, ed. D. Hall et al., Routledge Advances in Tourism, London 2002, pp. 17-19; J. Urry, Consuming places, Routledge, London 1995, p. 13. 
consequences, in revealing the socio-cultural impacts that cultural tourism might have on the local residents (host community). In our research we include an analysis of the various stakeholders such as the Local Authority of Centrum Borough, the Warsaw City Council, the Conservatory of Heritage in Warsaw Office, tourism industry, local community members; their priorities and visions of sustainable tourism development. We focused on the following key elements:

a) identifying the focal group of stakeholders for the Old Town in Warsaw; determining the potential interests groups and their point of view on tourism development;

b) examining the local community characteristic and background, its needs and expectations as well as visions for shaping the "shared space", revealing internal conflicts within local community members;

c) presenting the effort of Warsaw City Government to develop, validate and deploy a strategy of urban sustainable management, partnership and local community involvement aimed at creating a better tourism policy and improve the management, planning and implementation practices in Warsaw.

We regard the host community of the Old Town in Warsaw and its vision on tourism development (as presented in this paper) to be crucial for sustainability. Many scholars believe that the strategies for the heritage tourist sustainable development should be elaborated with the active participation of local communities, considered an important partner in the whole project process. ${ }^{5}$ However, with some limits, two approaches: the "bottom-up" and "top-down" should be combined to achieve sustainability. We intend to shape our research in the form enabling us to achieve applied results and hope to find a solution for the sustainable heritage tourism development. To measure these issues from different perspectives we use a combination of methods as we have aimed to achieve a balance between the quantitative and the qualitative approaches: the academic studies of published resources and spatial plans (the quantitative secondary data analysis) as well as the case study on the Old Town in Warsaw

B. Garrod et al., Managing heritage tourism, "Annals of Tourism Research" 2000, Vol. 27, No. 3, pp. 682-708; A. Apostolakis, The convergence process in heritage tourism, "Annals of Tourism Research" 2003, Vol. 30, No. 4, pp. 796-812; A. Panasiuk, Instrumenty polityki turystycznej w regionie, Prace Naukowe Uniwersytetu Ekonomicznego we Wrocławiu Vol. 50, Gospodarka turystyczna w regionie, Wrocław 2009, pp. 15-23; G. Richards et al., The community..., pp. 11-23. 
so as to obtain the primary data in the form of observations, semi-structured and structured interviews conducted between the local community and local authority representatives - as recommended by the well recognised researches in tourism. ${ }^{6}$

\section{Case study: the Old Town in Warsaw}

The Old Town in Warsaw (in Polish: "Stare Miasto" or, colloquially, "Starówka") is the oldest historic district of Warsaw. It covers about 10 hectares only and is framed by the Vistula River Valley in the East, the Central Town District ("Centrum" in Polish) in the South and the West, and the New Town District ("Nowe Miasto") in the North. The Old Town Market, located at the centre of the Old Town, well known for its numerous restaurants, cafes and souvenir shops, is commonly believed to be one of Warsaw's most prominent tourist attractions. Surrounding streets feature the medieval architecture such as the city walls, the Barbican and the St. John's Cathedral. The Old Town in Warsaw was established in the 13th century. Initially it was surrounded by an earthwork rampart; after the year 1339 it was fortified with the brick city walls. The Old Town originally grew up around the castle of the Dukes of Mazovia that later became the Royal Castle of Warsaw. The Market Square ("Rynek Starego Miasta") was laid out sometime in the late 13th or early 14th century along the main road linking the Castle with the New Town at the North. Until 1817 the Old Town's most notable feature was the Town Hall built before 1429 to be eventually demolished in 1817. The spacious Castle Square (today a forecourt to the Royal Castle) got its regular plan in 1644 to become a honourable setting for the King Sigismund The Third Column. In 1701 the Castle Square was again rebuilt by the famous architect Tylman von Gameren and later enlarged in 1818-1821 by the architect Jakub Kubicki. In the late 1930s, during the presidency of Stefan Starzyński, the municipal authorities began refurbishing the Old Town and restoring it to its former glory. The Barbican and the Old Town Market Place were partly restored. These efforts, however, were brought to an end by

6 J.T. Dallen et al., Heritage Tourism, Prentice Hall Harlow 2003; M. Finn et al., Tourism \& Leisure Research Methods, Pearson Longman Harlow 2000; K.M. Smith, Issues in Cultural Tourism Studies, Routledge, New York 2003; J. Phillimore et al., Qualitative Research in Tourism, Routledge, New York 2005. 
the outbreak of WWII. In September 1939, during the invasion of Poland, much of the district was badly damaged by the Nazis who targeted the city's residential areas and historic landmarks in the terror bombing campaign. A few years later, some of the hardest- fought battles of the Warsaw Uprising took place there. After the Warsaw Uprising (August-October 1944) what had been left was blown up by the German Army, utterly destroying the historic urban structure. The Old Town, as practically the whole left river bank town, was a sea of rubble and ruins. Some statistic data could picture this disaster: of Warsaw's 957 historical buildings - as much as 782 were completely demolished, 141 were partially destroyed, and only 34 escaped annihilation (what makes only 3\% survived of the total number). ${ }^{7}$ Most of the inhabitants of the Old Town were killed by the Nazis and the survivors were then moved out of the city. The remaining buildings were demolished and on January 17th, 1945 less than 5\% of the houses were still habitable. After WWII, the Old Town and the New Town were meticulously rebuilt with the use of the original bricks whenever it was possible. All decorative elements (or parts of) available - were reused and reinserted into original places. Often, Bernardo Bellotto's (Canaletto), 18th century vedutes were used as a source of information, very helpful during the reconstruction planning process. The line of the houses along the northern side of the Main Market (Dekert Side) were linked together in the post-war reconstruction and today their interiors house the Historical Museum of the City of Warsaw. The permanent exhibition shows plans, views, models and archive photos documenting the history of Warsaw from its beginning until contemporary period. The last historic monument to be rebuild was the Royal Castle (restored in 1971-1981), today the great landmark commanding the Castle Square. The Old Town reconstruction was very expensive, both in terms of money and communal effort. Despite the political feelings and attitudes in the post-war time, Polish workers together with the "inteligencia group" (middle class professionals) worked very hard, determined to rebuilt their city heritage. Their strong motivation and remarkable speed have gained them worldwide admiration. The Old Town in Warsaw has been on the UNESCO list of World Heritage Sites as "an outstanding example of a near-total reconstruction

Polish Urban Planning Society \& Warsaw Capital City Office (WCCO), Warsaw Physical Development, Polish Urban Planning Society, Warszawa 1997, pp. 21-45; Warsaw Capital City Office (WCCO), Warsaw Development Strategy, Warszawa 2007. 
of a span of history covering the 13th to the 20th century." ${ }^{\prime 8}$ Following the political changes after 1989 and the opening up for foreign tourists, the Old Town in Warsaw quickly has been recognised as a major tourist attraction. Today it has more than 200 shops, restaurants to potter around in. Moreover, when walking today through the Old Town narrow streets, it is hard to believe that practically most of the buildings are less than 60 years old.

The so-called "Decree on Municipalisation" announced by communists in October 1945 and concerning the ownership and use of land in Warsaw - cancelled private property rights to the land. In such a situation the "old" residences of the Old Town were given a communal apartment at the Praga District (located on the right bank of the Vistula River) and prestigious apartments at the Old Town were offered to the "specially selected" group of artists, scientists and highranked communist party members. It was not only about the unique location, but also the less restrictive area standard. The regulations at this time allowed, exclusively with regard to reconstructed historic buildings, occupying larger space and enjoy higher living standards. Contemporary residents of the Old Town (about 20000,7000 families) are representatives of the next generation. They are the children or even grandchildren of the first, post-war generation who used to inhabit the newly rebuilt district. Today this group of successors have only some tenantship rights (usually temporary) to occupy their apartment. Very rarely can one get a permission to buy an apartment from the state (or rather from local authority), many have few "strong" legal rights to the apartment s/he lives in except for the mere temporary "communal order." The lucky ones enjoying full ownership rights often take a chance to sell their property on the free real estate market. The price for one square meter of apartments located at the Old Town is one of the highest in Warsaw (usually more than $4000 \mathrm{EURO} / \mathrm{m}^{2}$ ). It is necessary to emphasize that the standard price for living space in the Centre of Warsaw is about $2500 \mathrm{EURO} / \mathrm{m}^{2}{ }^{9}$ Most of the ground floor commercial spaces (shops, restaurants) are owned by local authority (self-government) and are being let through the open auctions. The prices are very high (as it is popular tourist space) and no local grocery with basic food offer is able to compete and make profit. It is out of question that the commercial space in the Old Town should be - and is - used mainly for luxury restaurants, cafes, art galleries, antique

\footnotetext{
$8 \mathrm{http}: / /$ whc.unesco.org.

9 http://www.domiporta.pl.
} 
and souvenirs shops with silver, gold and amber jewellery. Rarely the owners are locals: unfortunately the Warsaw City Council Office was not supportive of local small-scale entrepreneurs (as artists selling their paintings in the streets), but supportive of the development of "quality" tourism and services based on luxury shops and restaurants. We cannot call it "fair trade" schemes and, obviously, any future benefits from tourism and economic development should reach all sectors of local community.

Our interviews with various stakeholder groups' representatives demonstrate that there is no one vision for sustainable tourism shared by local host community, conservatory office, local government and tourist industry. Regretfully, there are also differing levels of interests between individuals and groups within the local community, as the community is not homogeneous and not all local residents benefit equally from or are equally happy with tourism development. Moreover, we can observe individual and NGO's networks (Association of Warsaw Friends, Association of Old Town Local Community) rather than institutional efforts to practice sustainable tourism at the Old Town in Warsaw. Unfortunately, the recent documents on the Old Town Management strategy such as the "Warsaw Strategy of Spatial Development" (2007) and the "Management of the Old Town Strategy" (2012) both rely on general ideas and objectives than on a concrete action plan. ${ }^{10}$ This, therefore indicates a challenge in shaping other proposals for sustainable tourism planning recommendations. An important questions remain: how to make all stakeholders feel responsible to contribute in this process, and especially, how to involve the whole community in the tourism development? It seems that it is no other way to create a balance within the different interests groups than through the democratic process of making decisions (for example, through the Local Spatial Plan for the Old Town in Warsaw), as this system is giving equal weight to all legitimate voices. In 2010, one very promising step towards improvement of local self-government and democracy was the Warsaw City Council Office's (WCCO) decision to start two interesting projects: "Contribute in Architectural Relics Conservation Programme" and "Old Town New Image." Both projects were directed to local community members and intended as a new initiative to encourage people to express their opinions and to make them feel more responsible. What must be emphasized, in February 2010 the Warsaw

10 Warsaw Capital City Office (WCCO), Warsaw...; Warsaw Capital City Office (WCCO), Management of the Old Town Strategy, Warszawa 2012. 
City Council Office (WCCO) initiated a series of consulting meetings with the local community, regarding the Old Town Spatial Management, the Project "Old Town New Image." It was developed on the ground of the FSS's Norway Grants' Programme. ${ }^{11}$ There were several meetings launched on September 30th and October 5th, 13th, 19th, and 26th, 2010 enabling local community members to meet and talk with the Warsaw City Council Office representatives. The local community members had a chance to express their feelings and comments concerning heritage tourism future development at the Old Town and the New Town area. Unfortunately, only 250 out of 20000 inhabitants were present at least once, what makes hardly $1.5 \%$ of the total number of residents. Those interested in the project participation and present at the meetings mentioned several problems to be solved by the tourist development sustainable management plan. The necessity to shift public safety level (CCTV monitoring) and the sanitary issues (litters policy, provision of public toilets)were of primary importance. Later, other important questions concerning the organization of everyday life - parking places reserved for local residents, restaurants gardens blocking pavements, noise until the small hours - cropped up as well as those in regard of basic services (groceries, health services, transport) and the technical state of houses. The representative of disabled residents explained the necessity to secure a "barrier free" urban space, safer for the elderly, disabled and caretakers with prams thus indicating, that these improvements would be also important for disabled tourists visiting the site. The local community members highlighted that, in many cases, it is not possible to get the conservatory of monuments' permission to create ramps or wider passages. One of the important issues brought out was the creation of a tourist information system (with suggestions to use the late prof. Jan Zachwatowicz's ideas, including the "touch maps" system for people with sight impairments).

What must be underlined, we believe, is that, in the case of the Old Town in Warsaw, the sudden and sometimes uncontrolled development of tourism only highlighted the already existing inequalities and differences within the local community and its conflicts with the Warsaw City Council Office.

It must be stressed that most of the local community members were well aware of the many advantages connected with tourism development (e.g. the preservation of architectural relics and job creation). Despite the fact that

\footnotetext{
11 www.eog.gov.pl.
} 
it was very difficult to measure exactly these effects (especially the intangible impacts as promoting a better knowledge and understanding of Polish culture, tradition and history), it was obvious for these people that the meaning of tourism for the city economy was undisputable (Figure 1). However, the local community of the Old Town in Warsaw perceived the sustainable tourism development and the heritage site management possible under several conditions (field studies material 2012-2014):

- their approach is generally not anti-growth, but the host community wants certain limitations to this growth, and tourism development must be managed within these limits,

- limits should be set with regard to the environment studies, and nature and heritage protection requirements,

- long-term as much as medium and short-term thinking about tourist development are necessary (for example, the horizon of: 1 year, 5 years and 20 years),

- concerns for the tourism sustainable management should be seen also in the economic and social perspective of the host community, via their needs and expectations,

- all the stakeholders (including the local community) need to be consulted and empowered in tourism development decision making, need to be informed about the Warsaw City Council Office's plans, projects and actions within the Old Town and in its neighbourhood,

- final decisions of the Warsaw City Council Office concerning the Old Town must balance the costs and benefits in the context of not the local community as a whole as it is not a homogeneous group: there are various individuals and groups which could gain or lose in the consequence of different official courses and actions.

\section{Final Results and Conclusions}

When shaping our research aims we considered examining the complicated relationship between tourism sustainability and the local community of the Old Town in Warsaw the most important. There were complex interactions with the host community and the natural environment (Vistula River Valley), cultural heritage, the Warsaw Conservatory Office, the Warsaw City Council Office, and the commer- 
cial sector of tourist services. Our research has shown that there are several unsolved questions related to the tourist sustainable development management in the Old Town. First, there are visible signs of the physical damage at historic properties: wear and tear, litter and pollution, vandalism. Secondly, massess of tourists (throngs of people filling the narrow streets) and their sometimes antisocial behaviour, or noise they make until the early hours are mentioned as the major disruptions of everyday life. These were listed by residents of the Old Town in Warsaw, both during our interviews (in 2012-2014) and during the meetings organized by the Warsaw City Council Office (in 2010-2011). Most of the locals mentioned the lack of shops with food and very high prices at few groceries which are today in the minority. The majority of 248 shops operating in the Old Town and the New Town are either the famous restaurants or fancy boutiques and souvenir shops targeting rich tourists and less interested in submitting their offer to permanent residents. Local community members also suffer not having access to the basic services such as public transport (the Old Town is traffic-free zone), or having only very poor health services.

Sadly, very active only a few years ago, the Association of the Old Town Residents (founded in 2000) can no longer contribute effectively as a respected partner to the shaping of the spatial policy as potentially it could, for most of its members have not legal rights to their apartments. Without a clear position they are treated only as temporary tenants of communal properties and hence a "weaker" partner for the Warsaw City Council Office (WCCO) and the Warsaw Central Borough Local Authority (to which the Old Town and the New Town are formally incorporated). We would like to draw attention to the fact, that, in consequence, this could be a reason both for such a poor involvement of the host community in the sustainable tourism management projects and the indifference as regards participating in any other action aimed at improving the local environment (for example, the Krasiński Park of the Warsaw Restoration Project in 2011).

It is clear that the further development of tourism at the Old Town and the New Town requires taking into account not only the stimulating economic development through tourism and conservatory programmes, but also the views and opinions of various other stakeholders (local community, interest groups representing restaurants and shops holders, tourist agencies). As each stakeholder group has a different set of needs and ideas on how to use the historic urban fabric, it is necessary to solve some potential conflicts and achieve a balance between these voices. Although this theory is not very popular in tourism planning, it seems that the effort to identify, legitimate and make people feel involved and responsible 
should be the core of the sustainable tourism philosophy. However, scholars are right: the bottom-up approach alone cannot achieve sustainability, especially where control of the factors such as air and water pollution is necessary (possible only through top-down command) (Figure 1, Table 2). ${ }^{12}$

The example of not so successful project of the Warsaw City Council Office (WCCO) entitled "Old Town - New Image" (2010) showed that the Warsaw local community had not been ready to cooperate either with the self-government, or with government institutions. A mere $1.5 \%$ of local community members who so far have volunteered to contribute to the shaping of the sustainable heritage tourism strategy within the Old Town in Warsaw is not enough. If the goal of tourism management is minimizing the negative impact of tourism and protect the environmental and cultural heritage; to create tourist satisfaction and to stimulate economic growth; to provide improved living standards and environment quality for residents, than it is necessary to better understand the host community, its nature, scope and function as well as the political, economic and cultural tensions within the group. Understanding the way in which the community sees the problem solutions, the implications of their relations to tourists and tourists services should be a crucial basis to further the Warsaw City Council Office projects.

The sustainable site management requires to involve all stakeholders (that can affect or are affected by tourism) in the project, tourists visiting the site included. It seems that only through making "all of the groups" concerned with the sustainable tourism development we could successfully establish a more balanced and long-term effect in achieving goals. However, in order to obtain an equilibrium between the potential tourism growth, conservatory needs, and the quality of host community life, all stakeholders' interests and objectives regarding the tourism development must be incorporated into the Local Planning process and well balanced. It could be a way both to protect the outstanding values of the Old Town in Warsaw and ensure that tourists will get a quality

12 C.M. Hall, Tourism Planning, Prentice Hall, Harlow 2000; M. Hanzi, Information technology as a tool for public participation in urban planning: a review of experiments and potentials, "Design Studies" 2007, Vol. 28, No. 3, pp. 289-307; Ch.M. Law, Urban Tourism, Continuum, London 2002; S. Page et al., Managing Urban Tourism, Prentice Hall Harlow 2003; A. Panasiuk, Instrumenty zarzadzania turystyka w regionie, "Problemy Zarządzania" 2010, Vol. 8 (3/29), pp. 21-29; A. Pawlikowska-Piechotka, Planowanie przestrzeni turystycznej, Novae Res, Gdynia 2013; Y. Rydin et al., Public participation and Local Environmental Planning: The collective action problem and the potential of social capital, "Local Environment: The International Journal of Justice and Sustainability” 2010, Vol. 5, No. 2, pp. 153-169. 
experience there and the local community will feel a sense of responsibility when contributing to planning sustainable tourism (Figure 1, Table 2).

All in all, we have no doubts that the present planning process should be revised and the more integrated approach to local planning applied as an attempt both to solve spatial conflicts and build higher tolerance between local community members and tourists when sharing the historic space. Although UNESCO and ICOMOS provide a comprehensive set of universal guidelines, it is recognised that each historical place (as having unique values) requires an individual approach and spatial planning process must not be too much standardised. ${ }^{13}$ Therefore, our proposal for an integrated planning process for the Old Town in Warsaw has been aimed to address the unique features and specific nature of this site as well as find a satisfactory balance between conservation needs, heritage tourism development and the local community expectations (Figure 1, Table 1, Table 2).

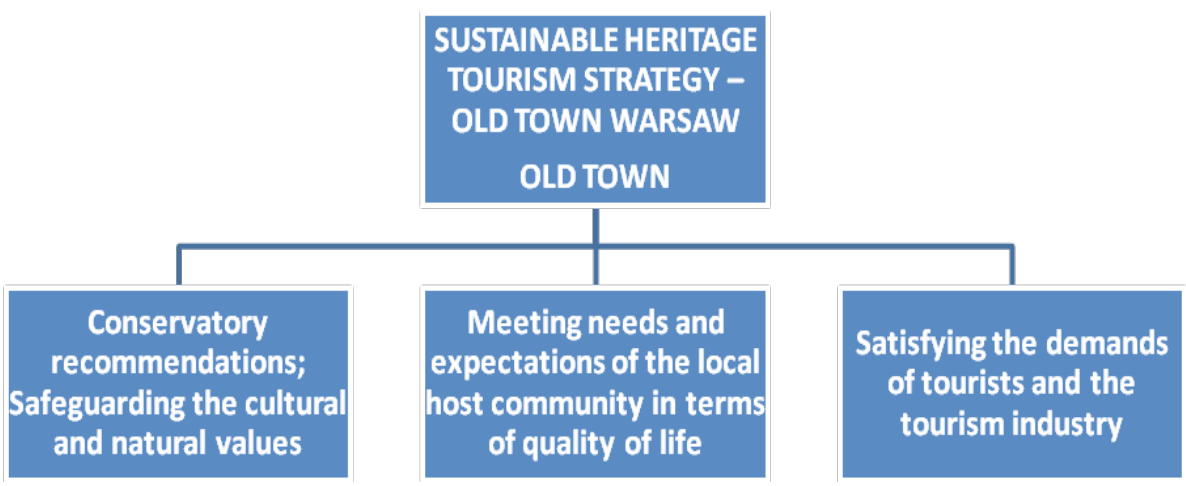

Fig. 1. Sustainable heritage tourism - sustainability goals of the main stakeholder groups (proposal for: Old Town Warsaw).

Source: research survey AWF University Warsaw (Ministry of Science and Higher Education, Poland grant: ds-144 AWF Warsaw).

13 United Nations Educational, Scientific and Cultural Organization, UNESCO World Heritage and Sustainable Tourism Programme - Action Plan 2013-2015, Paris 2011; United Nations Environment Programme, Rio Declaration on Environment Development, Rio de Janeiro 1992; United Nation Habitat, The Declaration on Cities and Other Human Settlements in the New Millennium, Nairobi 2001; United Nations Secretariat ENABLE, Convention on the Rights of Persons with Disabilities, New York 2006. 
Sustainable heritage tourism - proposals listed by the host community (the Old Town Warsaw)

\begin{tabular}{|l|}
\hline \multicolumn{1}{|c|}{$\begin{array}{l}\text { Principles listed by the local community members } \\
\text { as conditioning the sustainable tourism development }\end{array}$} \\
\hline $\begin{array}{l}\text { 1. Limits application to the growth and tourism development must be managed within } \\
\text { these limits }\end{array}$ \\
\hline $\begin{array}{l}\text { 2. Limits of tourist development should be set with regard to the environment studies, } \\
\text { and nature and heritage protection requirements }\end{array}$ \\
\hline $\begin{array}{l}\text { 3. Implementation of long-term, medium and short-term site management plans } \\
\text { concerning the tourist development is necessary (for example, the horizon of: 1 year, } \\
\text { 5 years and 20 years) }\end{array}$ \\
\hline $\begin{array}{l}\text { 4. Concerns of the tourism sustainable management should be seen through the economic } \\
\text { and social perspective of a host community, their needs and expectations }\end{array}$ \\
\hline $\begin{array}{l}\text { 5. All the stakeholders (including local community) need to be consulted and empowered } \\
\text { in tourism development decision making as well as informed about the Warsaw } \\
\text { City Council Office plans, projects and actions within the Old Town area and in its } \\
\text { neighbourhood }\end{array}$ \\
\hline $\begin{array}{l}\text { 6. Final decisions of the Warsaw City Council Office concerning the Old Town must } \\
\text { balance the costs and benefits not in the context of the local community as a whole, as it } \\
\text { is not a homogeneous group: there are various individuals and groups which could gain or } \\
\text { lose as the consequence of different official courses and actions }\end{array}$ \\
\hline
\end{tabular}

Source: research survey, conducted at Joseph Pilsudski AWF University Warsaw (Ministry of Science and Higher Education, Poland grant: ds-144 AWF Warsaw).

Table 2

Sustainable heritage tourism - integrated planning process proposal (the Old Town Warsaw)

\begin{tabular}{|c|c|c|}
\hline Phase & Integrated planning process & Outcomes \\
\hline 1 & 2 & 3 \\
\hline 1 & Goals, objectives and priorities identification & \\
\hline 2 & $\begin{array}{c}\text { Establishing goals within the tourism } \\
\text { development, local community expectations } \\
\text { and conservation requirements; identifying issues } \\
\text { and options; collecting and interpreting data }\end{array}$ & $\begin{array}{c}\text { Clear statement of plan } \\
\text { purpose }\end{array}$ \\
\hline Shaping possible spatial planning scenarios \\
$\begin{array}{c}\text { Examining trends in urban tourism (future } \\
\text { development trends), identify conservation } \\
\text { policy and philosophy (readiness for changes), } \\
\text { determining local community goals; preparing } \\
\text { draft plan and draft programmes for implementing } \\
\text { the plan }\end{array}$ & $\begin{array}{c}\text { Draft plan created - spatial } \\
\text { strategy of development }\end{array}$ \\
\hline
\end{tabular}




\begin{tabular}{|c|c|c|}
\hline 1 & 2 & 3 \\
\hline \multirow[t]{2}{*}{3} & Consultations & \\
\hline & $\begin{array}{l}\text { Presenting assumptions of the draft plan, } \\
\text { identify community primary values, key issues } \\
\text { and problems (through interviews and workshops), } \\
\text { identifying potential areas of spatial conflicts } \\
\text { (local community, travel agencies, government } \\
\text { institutions and NGOs - main stakeholders of Old } \\
\text { Town in Warsaw) }\end{array}$ & $\begin{array}{l}\text { Statement of agreed } \\
\text { vision of spatial policy } \\
\text { for sustainable tourism } \\
\text { development for Old Town }\end{array}$ \\
\hline \multirow[t]{2}{*}{4} & $\begin{array}{l}\text { Creation of the Local Plan for the Old Town } \\
\text { in Warsaw }\end{array}$ & \\
\hline & $\begin{array}{l}\text { Potential sustainable heritage } \\
\text { tourism development, conservatory } \\
\text { recommendations, solutions to spatial conflicts } \\
\text { and constrains of shaping "tolerant space", } \\
\text { details of infrastructure support (technical, } \\
\text { social, cultural, tourist services), programme } \\
\text { for architectural relics protection and historic } \\
\text { urban structure regeneration; evaluating potential } \\
\text { impacts of plans and implementing programmes }\end{array}$ & $\begin{array}{l}\text { Revise objectives } \\
\text { and strategies } \\
\text { Prioritised the programme } \\
\text { of infrastructure } \\
\text { and conservatory works } \\
\text { for the Old Town in Warsaw }\end{array}$ \\
\hline \multirow[t]{2}{*}{5} & Implementation & \\
\hline & $\begin{array}{l}\text { Devise implementation mechanism - programme } \\
\text { of work, organization issues, responsibilities, } \\
\text { timelines; identifying changes to existing } \\
\text { legislation }\end{array}$ & Implementation strategy \\
\hline \multirow[t]{2}{*}{6} & Consultation & \\
\hline & $\begin{array}{l}\text { Reviewing and adopting plan-implementing } \\
\text { programmes }\end{array}$ & $\begin{array}{l}\text { Concise Local Plan } \\
\text { for the Old Town } \\
\text { document outlining } \\
\text { all prior stages } 1 \text { to } 6\end{array}$ \\
\hline \multirow[t]{2}{*}{7} & Reviewing and monitoring & \\
\hline & $\begin{array}{l}\text { Reviewing and monitoring implementation } \\
\text { procedures }\end{array}$ & $\begin{array}{l}\text { Periodic reports } \\
\text { on implementation } \\
\text { andfurtherrecommendations } \\
\text { for the Old Town Local Plan } \\
\text { amendments }\end{array}$ \\
\hline
\end{tabular}

Source: research survey, conducted at Joseph Pilsudski AWF University Warsaw (Ministry of Science and Higher Education, Poland grant: ds-144 AWF Warsaw).

\section{References}

Act of Spatial Planning in Poland (1994) with amendments (Poland).

Apostolakis A., The convergence process in heritage tourism, "Annals of Tourism Research" 2003, Vol. 30, No. 4. 
Ashworth G.J., Heritage Planning: an approach to Managing Historic Cities, in: Managing Historic Cities, ICC, Kraków 1997.

Ashworth G.J., Whose history, whose heritage? Management means choice, in: Managing Tourism in Historic Cities, ICC, Kraków 1992.

Dallen J.T. et al., Heritage Tourism, Prentice Hall Harlow 2003.

Finn M. et al., Tourism \& Leisure Research Methods, Pearson Longman Harlow 2000.

Garrod B. et al., Managing heritage tourism, “Annals of Tourism Research" 2000, Vol. 27, No. 3.

Goetz D. et al., Stakeholder involvement in sustainable tourism: balancing the voices, in: Global Tourism, ed. W.F. Theobald, Elsevier, Burlington 2005.

Hall C.M., Tourism Planning, Prentice Hall, Harlow 2000.

Hanzi M., Information technology as a tool for public participation in urban planning. a review of experiments and potentials, "Design Studies" 2007, Vol. 28, No. 3.

Innes J.E. et al., Reframing public participation: strategies for 21st century, "Planning Theory \& Practice” 2004, Vol. 5, No. 4, DOI: 1080/1464935042000293170.

Lane M.B., Public Participation in Planning: an intellectual history, "Australian Geographer" 2005, Vol. 36, No. 3, DOI: 10. 1080/00049180500325694.

Law Ch.M., Urban Tourism, Continuum, London 2002.

Page S. et al., Managing Urban Tourism, Prentice Hall Harlow 2003.

Panasiuk A., Instrumenty polityki turystycznej w regionie, Prace Naukowe Uniwersytetu Ekonomicznego im Oskara Lange we Wrocławiu No. 50, Gospodarka turystyczna w regionie, Wrocław 2009.

Panasiuk A., Instrumenty zarządzania turystyka w regionie, „Problemy Zarządzania” 2010, Vol. 8 (3/29).

Panasiuk A., Instrumenty polityki turystycznej na poziomie regionalnym i lokalnym, in: Nowe wyzwania polityki turystycznej na poziomie lokalnym, regionalnym i międzynarodowym, Białystok 2011.

Pawlikowska-Piechotka A., Planowanie przestrzeni turystycznej, Novae Res, Gdynia 2013.

Paszucha M., Historic City Tourism and Polish Tourism Policy, in: Managing Tourism in Historic Cities, ICC, Kraków 1997.

Phillimore J. et al., Qualitative Research in Tourism, Routledge, New York 2005.

Polish Urban Planning Society (PUPS) \& Warsaw Capital City Office (WCCO), Warsaw Physical Development, Polish Urban Planning Society, Warszawa 1997.

Richards G. et al., The community: a sustainable concept in tourism development?, in: Tourism and sustainable community development, ed. D. Hall et al., Routledge Advances in Tourism, London 2002.

Rydin Y. et al., Public participation and Local Environmental Planning: The collective action problem and the potential of social capital, "Local Environment: The International Journal of Justice and Sustainability" 2010, Vol. 5, No. 2.

Selby M., Understanding Urban Tourism: Image, Culture, Experience, I. B. Tauris, London 2004.

Smith K.M., Issues in Cultural Tourism Studies, Routledge, New York 2003. 
United Nations Educational, Scientific and Cultural Organization: UNESCO World Heritage and Sustainable Tourism Programme - Action Plan 2013-2015, Paris 2011.

United Nations Environment Programme, Rio Declaration on Environment Development, Rio de Janeiro 1992.

United Nation Habitat, The Declaration on Cities and Other Human Settlements in the New Millennium, Nairobi 2001.

United Nations Secretariat ENABLE, Convention on the Rights of Persons with Disabilities, New York 2006.

Urry J., Consuming places, Routledge, London 1995.

Warsaw Capital City Office (WCCO), Warsaw Development Strategy, Warszawa 2007. Warsaw Capital City Office (WCCO), Management of the Old Town Strategy, Warszawa 2012.

\section{Internet sources}

www.intu.gov.pl. www.eog.gov.pl. www.whc.unesco.org. www.domiporta.pl.

\section{INNOWACYJNE ZASADY KONSULTACJI SPOLECZNYCH A ZRÓWNOWAŻONA TURYSTYKA MIEJSKA - STARE MIASTO W WARSZAWIE}

\section{Streszczenie}

Wielkie miasta są tradycyjnie popularnymi kierunkami wyjazdów turystycznych. Obecnie tłumnie odwiedzane w Europie: Berlin, Londyn, Paryż, Rzym; a w Polsce: Kraków, Trójmiasto, Warszawa, Wrocław - są dowodem na wciąż niesłabnące zainteresowanie turystów. Rosnąca powszechność turystyki miejskiej i w konsekwencji wzmożony ruch turystyczny w ich historycznych dzielnicach, $\mathrm{z}$ jednej strony powoduje liczne uciążliwości, a nawet dezorganizację życia codziennego mieszkańców, jednak równocześnie przyczynia się do ożywienia ekonomicznego, jest motorem rozwoju i cennym elementem promocji regionu.

Aby uniknąć lub minimalizować negatywne skutki tego zjawiska, a wzmacniać potencjalne korzyści - warto, aby władze miast były do takich sytuacji dobrze przygotowane z odpowiednim wyprzedzeniem, potrafiły wypracować racjonalne rozwiązania. Jest to szczególnie istotne na obszarach wrażliwych, o wysokich wartościach historycznych zespołów urbanistycznych (zabudowa staromiejska, cenne zabytki architektury i ich otoczenie). Dla osiągnięcia poszukiwanych zasad kompromisu pomiędzy grupami sprzecznych interesów, poza potrzebą honorowania rygorów ochrony konserwatorskiej, 
uwzględnianiem potrzeb turystów i inwestorów - ważne jest poznanie opinii społeczności lokalnej i włączenie stałych mieszkańców do wszystkich etapów prac nad planami strategii rozwoju turystyki i racjonalnym gospodarowaniem przestrzenią miasta.

Przedmiotem naszych badań prowadzonych w latach 2010-2014 było poznanie, na przykładzie Starego Miasta w Warszawie, zasad organizacji konsultacji społecznych w czasie procesu ustalania kierunków przyszłej strategii rozwoju przestrzennego dzielnicy, w tym perspektyw zrównoważonego rozwoju turystyki kulturowej. Interesowało nas poznanie stanowiska władz miasta, inwestorów, przedstawicieli instytucji pozarządowych oraz nade wszystkim opinii samych mieszkańców dzielnicy na temat pożądanych zasad harmonijnego gospodarowania ,,przestrzenią wspólną.” Artykuł prezentuje założenia i wnioski końcowe z przeprowadzonych badań w ramach projektu ds.-144 na Akademii Wychowania Fizycznego Józefa Piłsudskiego w Warszawie (grant finansowany przez MNiSW).

Słowa kluczowe: historyczne miasta, turystyka zrównoważona, konsultacje społeczne 